\title{
PERFORMANCE ART AS AN INSTRUMENT OF SPIRITUAL CONTEMPLATION: THE CASE OF THE MALAY WAYANG KULIT (SHADOW PLAY)
}

\author{
Tengku Ahmad Hazri*
}

\begin{abstract}
This article offers an interpretation of the wayang kulit (Malay shadow play) as a type of traditional art, in which the art forms are conceived within the broader cosmology derived from religious tradition. To this end, it focuses on three aspects of the play, namely, the rituals, mythology and symbolism in the setting to uncover their meanings and how these relate to the tradition in which it was conceived. As the play predates Islam and was immersed in animistic and Hindu-Buddhist milieu, it underwent reinterpretation to accommodate the coming of Islam and in fact was utilised to convey Islamic message by building on the people's pre-Islamic beliefs, thereby offering an instance of intercultural dialogue through art.
\end{abstract}

The Malay world as a repository of traditional art has often been overlooked by writers on the subject. By traditional art here is not meant simply an art form that has been around for a long time, but one that is conceived within a specific tradition conforming to the symbolism and laws of that tradition. The purpose of the art has been less for the privilege and luxury of the few than as an aid for man's contemplation towards the higher spiritual truths. The forms of the art are but symbols that collectively constitute the 'words' begotten upon the union of 'letters', serving as the stepping stone for man to penetrate them and fathom beyond appearances to the world of meaning, indeed, to the contemplation of the Divine. That many of these arts survived today as a legacy from the distant past is in itself testimony to man's resilience in holding to the last vestiges of the sacred even as the modern world constantly seeks to relegate it to the Museum of Superstition. This is evident if one considers the Malay shadow play, or wayang kulit, which, despite the preponderance of MTV and Hollywood blockbusters, had nevertheless endured till today with all its traces of the occult, magic and mystical practices. Deciphering some of the spiritual symbolism present in this art will be the aim of our discourse, and we will explore in particular, the wayang's unique ways of defining the relations between the immanent and the transcendent. To this end, we will investigate not only the technicalities of the art, but also its myths, setting, rituals and even the training of the dalang (puppeteer). 


\section{An Introduction to the Wayang Kulit}

Wayang kulit, the Malay shadow play, is a form of folk entertainment that makes use of the principles of light and shadow, involving puppet play moved and manipulated by the performer or puppeteer, known as the dalang, behind a white screen (the kelir) of a small, raised hut known as the panggung [Figure 1]. The puppets themselves are made visible to the audience as silhouettes or shadows [Figure 2], made possible by the presence of light, often through light bulbs or paraffin lamp, suspended between the dalang and the screen, and directed towards the screen from behind it [Figure 3].
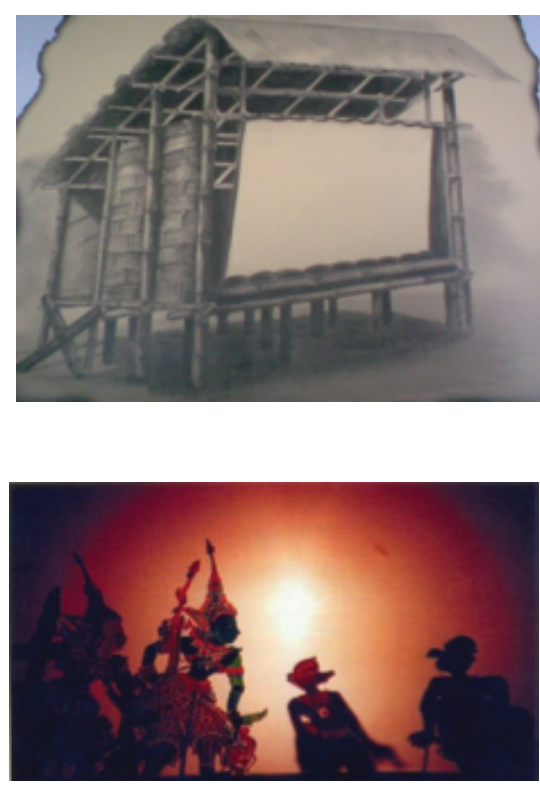

Figure 2: The puppets of the play are shown as shadows from behind the kelir

Figure 1: The Panggung. The white screen is known as the "kelir"

fom be

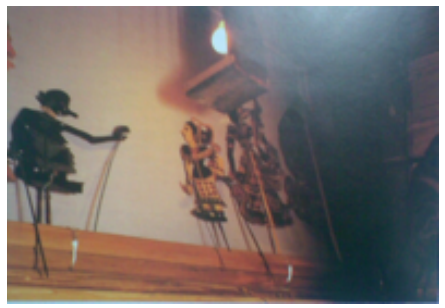

Figure 3: The view from behind the kelir - the shadow player performing with lamp suspended between him and the puppets. 

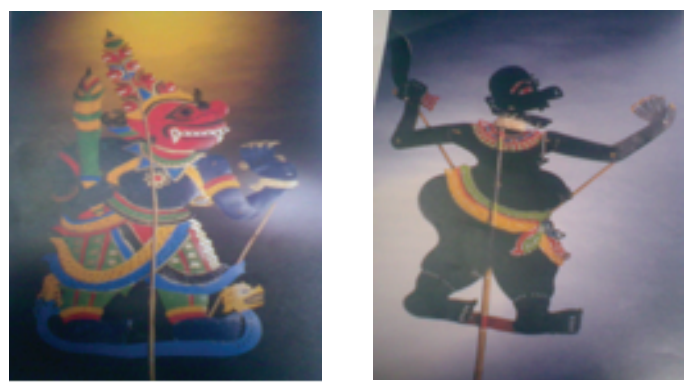

Figure 4: Maharaja Wana (left) and Pak Dogol (right). The puppets from the Hindu epics usually stand on a serpent or dragon. Most of the characters hold a weapon on one arm.

Performance is typically accompanied by traditional music and is often preceded by a series of elaborate rites and rituals, involving invocation of spirits and supernatural powers, purportedly to protect the performance from evil influences as well as in captivating the attention of the audience. For obvious reasons, the shadow play is carried out at night, and occasionally done, not for purely entertainment's sake, but towards more spiritual and exorcist ends. ${ }^{1}$ Although originally enacted only on specific events, such as circumcision ceremonies or the harvesting season, contemporary times have witnessed the flourishing of the wayang kulit largely as popular entertainment or cultural phenomenon, by virtue of which it has become an important tourist attraction. In the Peninsula Malaysia today, at least four types of wayang kulit are to be found, namely the wayang Siam, wayang Jawa, wayang gedek and wayang kulit Jawa. ${ }^{2}$ Our research will focus on the first, namely the wayang Siam of Kelantan, insofar as it is the most well-known among the various wayangs.

The puppets of the Malay shadow play are made from leather, hence the term wayang kulit, literally meaning "leather play" (wayang = play; kulit = leather). The design of the puppets shows a remarkable variety of influences. Like those of the Nang Talung, a type of shadow play from Thailand, the majority of the characters of wayang Siam have only one movable arm, with the other arm holding a weapon, and often standing upon some kind of a 'transport' made up of various creatures such as serpents or dragons [Figures 4]. Moreover traditional male characters are similar in appearance, both featuring the typical Thai pinnacled crown although they are different in form. ${ }^{3}$ It has also been suggested that the structure of the characters of Rama and Hanuman in the wayang Siam reflects some elements tracing back to India, not to mention other sources, most notably to Thailand and Java, to such an extent that northern Peninsula Malaysia - of which Kelantan is a part - has been described as a "shadow-puppet melting pot." Interestingly enough, notwithstanding the myriad of origins that have shaped the Kelantanese shadow play, the puppets have nevertheless evolved structures unique and distinctive to its homeland Malaysia. ${ }^{5}$ 
The repertoire of the shadow play revolves around the story adapted from the Hindu epics of Ramayana and Mahabharata, particularly in its localised Malay variant, the Hikayat Seri Rama (The Epic of Seri Rama) and the Hikayat Pandawa Lima (The Epic of the Five Pandava Brothers), but especially in their popular folk version, the Hikayat Maharaja Wana (The Epic of Lord Ravana). Now in these localised editions, some of the original characters assume new names. Hence Rama becomes Seri Rama, Sita is Siti Dewi, Hanuman is Hanuman Kera Putih (Hanuman the White Ape) and Ravana is Maharaja Wana. For the sake of performance however, the dalangs are torn between remaining faithful to this central plot and keeping the audience's interest alive (i.e. the audience would have been bored if the same plot is enacted over and over again). Ironically, the audience themselves are hardly fond of 'new' stories, preferring instead, to indulge in tales garbed with claims of their timelessness and primordiality. That is why stories for the play are divided into the cerita pokok (trunk story) and the cerita-cerita ranting (branch stories), with the former being stories drawn from the original epic while the latter new stories presented as extensions of the original narrative. In brief, the Hikayat Maharaja Wana tells of the events in the sky kingdom (Kayangan) prior to Seri Rama's birth, then goes on to explain about his birth, along with his brothers. Then as the story unfolds, Siti Dewi's heart was won over by Seri Rama when he emerged victorious in an archery competition organised by her father, Maharisi Kala Api, after which the jealous Maharaja Wana - who lost the game to Seri Rama - kidnapped her to Langkapuri. Seri Rama and his brother then embarked upon a quest to rescue her, during which he encountered Hanuman Kera Putih, the son he never knew he had, who generously offered to be part of the fellowship. After many trials and tribulations, Maharaja Wana was defeated and Siti Dewi freed from his hands. The cerita-cerita ranting use the same basic characters and main storyline, but are varied as pleased by the dalangs - all in their effort to preserve the legacy of the wayang among the common folks.

A typical performance of the play also includes recitation of mantras, along with other rites and rituals. Already here it can be seen that the shadow play is not reducible to its appearance as 'profane' human drama enacted in puppet forms, but instead is steeped within the mysteries of occultism and spiritual practices. These rituals include the jampi (chants or spells), kenduri (feast), buka panggung (rites to commence the theatre) and berjamu (ritual performance). ${ }^{6}$ The wayang often begins with salutations upon supernatural beings and before the introductory music starts, the jampi is recited along with the numerous offerings in the kenduri, from food to cash payment, and invoke upon the power of such beings as hantu (ghosts), jinn (genies), jembalang (hovering spirits) and even the "original teacher" of the dalang. ${ }^{7}$ The purpose apparently is manifold, ranging from the protection of the performance from subtle malign influences 
and winning the audience's attention to calming the audience and subduing the possibility of fights and quarrels among them. In other words these spells and magic work as a force-field generator that not only serve as protective measures but to transport the entire performance to a cosmos unto its own, 'locking' and binding the shadow player and the audience to one another.

The shadow play is by no means exclusive to the Malay world. Similar theatrical forms are equally found across Southeast Asia and even beyond. In Malaysia and the Indonesian islands of Java, Bali and Lombok, it is known as wayang or wayang kulit; in Thailand and Cambodia, the term nang (and also ayang in Cambodia) is used. Outside this region, it is also found in India, China and Turkey, and even extinct forms in Iran and Egypt. ${ }^{8}$ Historically, the art itself has been around for centuries. The earliest reference to shadow puppetry appear in the Jataka tales (Buddha's birth stories) of India, around $200 \mathrm{BC}^{9}$; the Piyingxi, or shadow play of China, is said to date back 2000 years to the Han dynasty ${ }^{10}$; the classical Javanese shadow play (wayang kulit Purwa) has been confirmed to have existed from about the $9^{\text {th }}$ century ${ }^{11}$; while the earliest Malay shadow play of Kelantan has been traced back to the reign of Long Yunus (1763-1798) in the $18^{\text {th }}$ century. During that period, the play had its headquarters in the Court of the Raja (King) of Patani, and "appeared in Kelantan in the rather unsettled surroundings of Long Yunus' Balai [Court] when circumstances were favorable." 12

\section{Islam-Wayang Encounters}

The shadow play being in existence long before the coming of Islam to the Malay world, naturally this new religion that settled here some centuries ago was bound to confront the pre-Islamic heritage of its new abode. Reaction was by no means uniform, but it has largely been less favorable to the eyes of official religious authorities than to the common people. Objections to this art assume many different forms. The rites and rituals of the wayang, particularly the recitation of mantras (jampi), are said to contain syncretistic formula that mix animistic, Hindu and Islamic elements. ${ }^{13}$ Theologically this is deemed to be a serious threat to the aqidah (central belief) of the Muslim. In the more social and practical dimension, critics are apt to point out the so-called immorality of the dalangs, including their lack of discipline in observing even basic injunctions of the Shariah such as the hajj (pilgrimage to Mecca, one of the five pillars of Islam), while some are said to be womanisers by abusing spiritual knowledge acquired through dalangship to make themselves appear as darlings to the chics. ${ }^{14}$ Others find fault in the symbolism of the play, arguing that the dalang's performance of the shadow play is analogous to God's control of man and the universe, and hence the dalang here is seen as "playing God", a point which we will return to later. 
Despite the various rituals that appear to sanctify Islamic message in the play, an important observation of its practitioners nonetheless hints something about the seemingly "irreligious" dimension of the art. We have noted earlier that a common criticism of the dalangs is that few of them actually went to perform the hajj. ${ }^{15}$ Although this alone is scarcely a fair basis for the harsh verdicts made against them (for this could be due to lack of financial resources or other factors), those who did perform the hajj are noted to have actually abandoned their art upon returning home and "repented" for having practiced it for so long. Some who claimed to have met Prophet Muhammad (may peace and blessings be on him) in their dreams too decided to forsake the world of the wayang. Exactly how far the practice of wayang kulit violates the principles of Islam is by no means easy to assess, and we will not make such an attempt here, as it is a research project unto itself. But one is inclined to think that the wayang, or the dalangship per se is not intrinsically un-Islamic, as testified by the teacher of the famous dalang Dollah Baju Merah, who, having cast his dalangship aside and left his practice following a dream of meeting the Prophet, nevertheless continued teaching it. ${ }^{16}$ One possibility is that, rather than leaving the art altogether, he saw something valuable in it - perhaps sympathising with its function as an instrument of support for spiritual contemplation, which we will discuss later and therefore seek to "Islamise" it "from within" by going through the very roots of the wayang, namely, the education of dalangs.

\section{Wayang Kulit: Myths and Genesis}

Turning now to the mythology that sustains the wayang kulit, one may readily appreciate that myths serve not only as symbols that reveal a wealth of meanings but also elevate the art form from the ranks of folk plays to the vehicle that conveys higher spiritual messages. It is precisely myths that accord the art its aura of timelessness and sacred dimension - a claim not altogether false if one considers the historical origins of the wayang kulit. Even by a myth-free historical account alone, theories abound as to its genesis and many attribute it to a cult of ancestor worship among the primitive tribes of Nusantara. It was believed that the spirits of the ancestors (called hyang) could be summoned for their aid and magic by making images and puppets to induce their presence and 'capture' them on these forms. These images and puppets serve as the temporary abode in which the souls may dwell in brief while the worshippers plead for their guidance. ${ }^{17}$ The puppets are thus the rendezvous where the spiritual and the corporeal intersect, a meeting point between the Divine transcendent and the earthly immanent. Only by this means that profane men can communicate with all that partakes of the sacred. While this ancient theology to which wayang kulit was bound does not 
survive the passage of time, residues of the spirituality that underpins the art are nevertheless still observed today, as can be seen in the elaborate mythology that surrounds the wayang.

In its earlier form, the play is said to have been first brought to earth from the kayangan (the heavens) by a certain Pak Dogol (one of the main characters in the Wayang Siam), who is actually Dewa Sang Yang Tunggal (The One Great One), the highest Dewa (God) of the kayangan. He was bored of living alone in Paradise and wished to observe his subjects, and thus descended to earth as a hideous old man. Out of his bodily dirt, he created what later came to be his companion, Wak Long. Now in this sense, it has been suggested that, while many would not have confounded the Sang Yang Tunggal (and by implication, Pak Dogol) (The One Great One) with Allah Himself (The One God), there are others who would have succumbed to such confusion. ${ }^{18}$ But this mythological account has nevertheless been replaced with another, which seemed to be less religiously objectionable.

For many dalangs today, there is a general agreement that the wayang originated from a certain Haji Mula (literally, the first Haji, one who has performed the hajj), but the silsilah or chain of evolution, explaining his transmigration from one form to another, culminating in Pak Dogol, varies from dalang to dalang. A noteworthy interpretation is that Haji Mula was originally the Angel Azizin who resided in the kayangan before the creation of Adam, the Prophet and first man. Once Adam was created, all was commanded by Allah to prostrate before the new creature, but the Angel Azizin refused, insisting that he was created first, hence more honour and glory lie in him rather than this more recent creation. Furious, God banished him from Paradise and he underwent a series of evolution - or rather de-evolution - in which he degenerated into Haji Mula, and later on, a hideous atavism called Pak Dogol. Angel Azizin was once beautiful, but is now ugly and forbidden to touch anything that belongs to God. Left to himself, unable to even clean his body, he grew bodily dirt to such an extent that it became a new being, which came to be known as Wak Long. The wayang is said to be brought to man by Pak Dogol, i.e. Haji Mula, who was the first dalang. Both Allah and Prophet Muhammad were claimed to be the original teachers of the art. ${ }^{19}$

The mythological revision narrated above may sound gibberish, but we believe there may be something more substantial to the story than a superficial "Islamisation" of the art by means of name-changing and giving central prominence to religious personalities. To the contrary, the mythological revision and the exposition of an elaborate silsilah, tracing the genealogy of the art back to its Divine Source in this respect perfectly mirrors the attitude common among practitioners of traditional art, namely, rather than remaining heedless to the influence of the new religion, or even dismissing it as irrelevant, the puppeteers have taken upon themselves to re-interpret the myth of genesis and made it more 
in tune with Islam. The point is less to appease to the common want of religious justification for the art than for the realisation among the art practitioners themselves, that the original myths represent certain spiritual archetypes utilised to convey supra-formal meanings. Yet these archetypes are strictly bound to the religious tradition - which serves as the 'language' for the symbols so to speak - within which it has been conceived, that is to say, as the receptacle to receive the message. Once the tradition makes way for another tradition, it makes perfect sense to "translate" the message into the new language, i.e. the new tradition, and hence the necessity to revaluate the role of the symbols, while simultaneously remaining faithful to the original message.

One may cite two examples to illustrate this point. The first is the creation of Wak Long from Pak Dogol's body, which is reminiscent of the creation of Eve from Adam's rib. His refusal (in the earlier form of Angel Azizin) to prostrate before Adam finds its parallel in Iblis' similar reaction towards the creation of Adam, and since Adam was only created once, one is apt to identify Pak Dogol with Iblis. Such could have doubtless been the interpretation had the story ended there, but it doesn't and Pak Dogol's saga continued. Unlike Iblis, Haji Mula sought repentance from God after his banishment from Paradise. This element of repentance is crucial to Islamic theology, for it was Iblis' despair, hopelessness and incredulity in God's mercy that led him to be known as Satan, for the Quran has constantly reminded man to "not despair of God's mercy for none despair of God's mercy except unbelievers" (Q Yusuf,12:87). This is why Haji Mula, despite the gravity of the punishment against him (he was denied everything that partakes of God's creation), nevertheless did not surrender his hope in God, the Most Merciful (al-Rahman) and Most Compassionate (al-Rahim). The second is the juxtaposition of characters belonging to different traditions with one another, partly as a device to invite the audience to rethink their perception and judgment about certain characters of the play, which represent specific religious symbol. This is why in the shadow play, Pak Dogol, an abstraction of a personality belonging to various traditions, is made to encounter the heroes of Hindu epics, which calls for one to come to terms with a dialogue between the two traditions of Hinduism and Islam, precisely the transition that the wayang itself, not to mention Malay society, has had to confront.

\section{Symbolism in the Repertoire: The Universal Archetype and the Symbolic Expression}

As an instrument of support for spiritual contemplation, discernment between the Absolute and the relative in traditional art is extremely critical. The wayang's device in accomplishing this task is through the repertoire, namely, 
by distinguishing between what is perennial or universal and what is transient or particularised expression of the universal. Now this aspect is especially evident in the very structure of the wayang stories. To describe the relations between the narratives, the dalangs employ a tree imagery, with the 'trunk' being the main story of the Cerita Maharaja Wana (Story of Lord Ravana), the 'original' epic drawn from the Ramayana or Mahabharata, and the 'branch' stories (cerita-cerita ranting) being minor tales or anecdotes drawn from the main saga. Whereas the trunk originates from a clearly defined source, namely, the two Hindu epics, the cerita-cerita ranting are exhausted only by the creativity of the dalangs. The branch stories however, are not radically new innovations but rather extensions of the original story. Characters from the principal myths are retained but are now made to confront new situations, such as a battle against new raksasa (demons). Minor characters may sometimes be added to the branch story but the chief dramatis personae have always been the authentic mythical figures. This then, is the crucial point: the universal and the particular in the repertoire are represented by the trunk and branch stories respectively. This is why, despite the myriad of branch stories authored by the dalangs, the mere presence of the mythical heroes and villains is reason enough to secure their dependency upon the original source. Who is Seri Rama? Why is Maharaja Wana so hostile towards him? Constrained within the universe of the cerita ranting, one is apt to be left with dismay and disappointment in learning that answers cannot be found for these curiosities. Only by transcending this relativity and returning to the source of the narrative will the truth be revealed. The universality of the trunk story stems from its very conception within a world of a primordial tradition. It is thus the archetype containing within it manifold possibilities for manifestation in the world of change, becoming and multiplicity. Like the centre of the circle, the trunk story is what radiates and illuminates all the cerita-cerita ranting which are like its circumference. For this transcendental archetype to be accessible to the world of immanent, one cannot thus bypass the contingencies in which man finds himself, such as the cultural and psychological peculiarities or even the predominant mood or temperament of the day. The diversity of the human receptacles is thus a factor in determining the mode of archetypal expression. For this reason the dalang's role in producing a compelling cerita ranting that is able to engage the audience while at once remaining faithful to the perennial message that he seeks to convey, lying at the back of his mind, is pertinent. This explains why "the majority of dalang are somewhat loath to admit that they invent tales involving the characters of Ramayana" as they deem this central plot to be "most inviolable. ${ }^{20}$

The nexus between the immanent and the transcendent, between the relative and the Absolute is further testified by how the characters in the shadow play 
interact with one another. Of special note here is how the mythical characters deal with Pak Dogol and Wak Long. These latter two characters form an essential component of the wayang Siam repertoire but are nevertheless absent from either the Hikayat Seri Rama (the Malay literary rendition of the Ramayana) or the Hikayat Pandawa Lima (the Mahabharata). ${ }^{21}$ Now at this juncture it is perhaps safe to contend that their appearance is thus exclusive to the wayang Siam story, and that for as much for entertainment as for serving symbolic purposes. Our contention here is that Pak Dogol represents a form of particularisation of a spiritual archetype and his role as clown-servant to Seri Rama or the Pandava brothers demonstrates the subordination of the particular to the universal; that the particularisation of the symbol is meant to serve the meaning of the symbol.

This claim that Pak Dogol as particularisation of universal symbol is supported by the fact that, while he assumes this personality solely in the wayang Siam of Kelantan, his resemblances are nevertheless to be found throughout the region. He is known variously as Semar, Dewa Sealam Tunggul, Empu Purwa, Sang Adi Putra and Dewa Agung Kepala Sekalian Dewa in different parts of Southeast Asia. ${ }^{22}$ This is so even when there are dalangs of wayang Jawa who wished to refute any such association between Pak Dogol and Semar, for "the explanation of the origin of Semar... is nearly the same as that told about Pak Dogol." ${ }^{23}$ Pak Dogol accordingly is a 'native' of Kelantan, born here as a specific reincarnation of an abstract, nameless entity that manifests everywhere in the area, assuming different names. One of the tasks of the dalangs is to make Pak Dogol and Wak Long especially agreeable to the audience, for that is what a particularised symbol does, namely to address the peculiar traits of the human receptacle. To accomplish this, these characters are conferred an interesting attribute - as the comic relief for an otherwise solemn performance. In one of the cerita ranting, called the Kerak Nasi or Nasi Dingin repertoire, the dalang even explored a conflict between Seri Rama and Pak Dogol, in which the latter was driven out of the palace on account of his lowly origin and some simple mistakes. Eventually, Seri Rama had to pay a heavy toll for this unjustified action. ${ }^{24}$ This repertoire lucidly illustrates how symbols, while often misunderstood and misconstrued, are nevertheless needed as the vehicle for transcendental meaning to express itself.

\section{Symbolism in the Setting}

The setting of the wayang is also symbolic and in some cases this has also been the source of controversy behind the peculiarly "un-Islamic" character of this art. One interpretation proposes that the panggung represents the universe, the macrocosm so to speak, in which man lives and breathes. The follies and foibles of the puppets are those of us mortals; the white screen is the sky or the face of 
the world; the lamp is the sun which enables there to be day and night; while the dalang is none other than God, the invisible puppeteer who controls and lords over all of creation that is the puppets of the shadow play. Indeed, there is a common expression in the Balinese and Javanese cultures of Indonesia - to which the wayang Siam traces some of its influences - that "life in the world is like puppet, we are controlled by a dalang - the God." ${ }^{25}$ What many find disturbing therefore is the religiously unpalatable thought that the dalang here is 'playing God', an act that verges easily upon the serious possibility of slipping into shirk (putting anything at par with God, a grievous crime in Islamic theology and jurisprudence). Nevertheless, a closer scrutiny reveals such a macrocosmic interpretation of the setting to be untenable and a more persuasive case is to understand it as the microcosm, or specifically, man as the microcosm, the small world or miniature universe in whom all that exists in the world is reflected.

This re-conceptualisation accordingly carries with it the necessity to revaluate the macrocosmic theory of the panggung, which seems to be vindicated by lucid accounts of the structure of the cosmos as elaborated by the dalangs. The localised (i.e. the Indonesian origin) Hindu cosmology's concept of tri angga, or three-fold division of the world into the holy (utama angga), intermediary (madya angga) and profane (nistha angga) was applied to the organisation of the panggung. ${ }^{26}$ But at the same time, this trinitarian logic was extended to connote the life cycle of man, symbolised by the three stages involving the puppets - awakening them from their sleeping box, making them move and unfold the story, and finally to return to their 'slumber' in the box, equivalent to the mortal process of birth, life and finally, death. Now what this reveals is the intersection or correspondence between the universe as the macrocosm and man as the microcosm. To be clear, this outlook only has sanctity insofar as it is sustained by animistic or Hindu cosmology. Post-Islam as mentioned, this macrocosmic identification became less tolerable, and hence shifts the paradigm towards a more firmly rooted microcosmic vision of the wayang. Islam's influence, expressed in symbolic terms, is accordingly to absorb the weight of the cosmos and places it solidly on man as God's vicegerent on earth. The dalang is no longer the 'invisible God' but man's deepest self, and the entire shadow play is to be construed as the drama that unfolds as man journeys to comprehend and realise his innermost being. In the process, the dalangs employ many devices lest the audience sheepishly succumb to the superficiality of appearances and overlook the reality beyond the shadows. This is easily attested by how the puppets themselves were lavishly colored, beautified and adorned, yet are only as shadows during performance. Even as the narrative had begun, the dalangs frequently remind the audience not to be deceived by appearances, as seen in how Dollah Baju Merah warns that Pak Dogol should never be misjudged for his less-than-pleasant looks. ${ }^{27}$ If 
only the audience knew the myth and semi-theological underpinnings of the play, Pak Dogol would have fared better in their eyes. Hence the need to probe what goes on inside the panggung, for this is where the truth lies, not in the cheers and jeers among the masses outside. Man must constantly seek within himself for the ultimate questions, not outside.

But man is not an alienated being. He is inescapably bound to his Creator whom he will encounter at the very substratum of his soul, for "he who knows himself, knows his Lord." ${ }^{28}$ His Creator then is only accessible within the cadre of religious tradition, which necessitates discipline in following the Divine decree. ${ }^{29}$ Now this results in the formulation of elaborate rituals in the shadow play that secures one strictly along the path of God. One of the rituals pertaining to setting of the panggung is that it cannot be directed to face the Ka'bah, ${ }^{30}$ presumably to prevent the audience from turning themselves against the Ka'bah, the spiritual center of this world, for doing so metaphorically places oneself in opposition to the religion - from which the art itself finds its legitimacy - whereas one cannot possibly become acquainted with one's inner self by abandoning one's faith. This is further reinforced by the performance of other rites designed to ward off evil spirits while the wayang kulit is being performed.

Once the performance begins, what takes place can be understood from two levels. One, is the straight-forward depiction of folk entertainment at work. On another level, what actually happens is this: the dalang is engaged in a process of spiritual contemplation largely to the oblivion of the crowd. In doing so, he makes use of the visible acts and expressions which veil a wealth of inner, esoteric and mystical dimension, analogous to the performance of salat or Hajj, or even the dances of mystical cults (e.g. the Whirling Dervishes), which nevertheless can be discerned by the few who possess the requisite temperament and disposition of the soul to fathom their mystique. In wayang parlance, such persons are said to be in possession of the right angin, literally meaning 'wind', but here denotes a certain inner proclivity or inclination towards the secrets of the art. ${ }^{31}$ A dalang will only impart his knowledge if the prospective student possesses this angin. Once he is accepted as a pupil, the latter will then accompany the master to performances as apprentices, occasionally performing the opening ceremony, or even some basic repertoire under the guidance of the master. The knowledge that will be handed down is not only that pertaining to the performance but also contain some elements of magic or occultism. Two forms of knowledge are imparted, namely, the ilmu luar (outer, or exoteric knowledge) and the ilmu dalam (inner, or esoteric knowledge), the latter of which involves hidden knowledge useful in protecting the dalang's art from demons, evil spirits and other influences ${ }^{32}$ as well as engaging the audience and other uses, but also can be abused, such as in making himself irresistible to women. When the student 
is ready to 'graduate', the master will perform a special rite called pelimau, or bathing with flowers, to mark his 'convocation'. Thus it can be seen here that the shadow play performance also serves as a form of semi-initiation into the art, with the majority 'failing' this test, while the few with the right will and angin will be sparked by intense curiosity enough to approach the dalang and plead for his knowledge, who will then welcome him into the occult world of the wayang circle. This then, distinguishes wayang kulit from many other traditional arts, which require initiation to be conveyed their mysteries. The wayang is involved in spiritual initiation even at the very 'profane' level as folk entertainment.

\section{Conclusion and Recommendations}

The wayang kulit has evolved significantly from its pre-Islamic roots to a new presence in an Islamic milieu: its symbolism reinterpreted, its myth retold and its setting and structure seen in a new light. It remains today one of the few legacies of traditional art inherited from the pre-Islamic times of the Malay world and beyond. As befitting the perennial message that it seeks to convey, the wayang was able to adapt itself to the new religion of Islam that settled here some centuries ago and was indeed integrated into the very fabric of Islamic culture and civilisation, even as it has been constantly besieged by exoteric religious authorities. What accords this art its timeless message is its role as support for spiritual contemplation, as a spiritual autobiography narrated in symbolic forms, of man's effort to realise the formless transcendent in the world of forms and relativities. So long as this primordial view of art lingers with the play, its heritage will continue to mark its presence in the years to come. Towards preserving such heritage, it is suggested that:

- The wayang kulit should be more prominently highlighted in relevant cultural and educational programmes as an instance of intercultural dialogue through art particularly in a society's transitional phase from its pre-Islamic origin to the coming of Islam.

- An appreciative view of traditional arts should also be cultivated among the populace by linking these arts to the religious and spiritual cosmologies within which they are conceived. Such an approach would nurture a more accommodative spirit towards artistic practices that may at first glance seem religiously objectionable.

- The potential role of traditional arts in propagating the message of Islam should also be explored in greater depth. 


\section{Glossary of Malay Words}

Angin: literally, "wind" but in wayang terminology, the inner propensity towards the art.

Berjamu: ritual performance.

Buka panggung: rites to commence the shadow play ceremony.

Cerita-cerita ranting: 'branch stories', extended narratives of the shadow play drawn from the 'trunk story' or cerita pokok.

Cerita pokok: 'trunk story', the main repertoire of the shadow play, taken from the Hikayat Maharaja Wana, inspired by the Hindu epics of Mahabharata and Ramayana.

Dalang: the puppeteer or shadow player of the wayang.

Hantu: ghost.

Hikayat: epic.

Jampi: chants or spells.

Jembalang: hovering spirits.

Jinn: genies.

Ilmu dalam: inner, or esoteric, knowledge; the magical or occult elements involved in the training of the dalang, usually imparted once trust with the teacher is secured, and is the last form of instruction in the training.

Ilmu luar: outer, or exoteric, knowledge; knowledge pertaining to the technicalities of the play, including the skills in handling the puppets and the repertoire.

Kayangan: The Heavens, or Paradise. In wayang mythology, this is where Haji Mula or Pak Dogol originates from. In the Hikayat Maharaja Wana, the abode of Seri Rama and his brother Lakshmana.

Kelir: the white screen of the panggung through which shadow puppets are shown to the audience.

Kenduri: feast.

Panggung: a small raised hut from which the shadow play is performed.

Pelimau: bathing with lime and flowers, a ritual ceremony to mark the 'graduation' of a pupil from his dalangship training.

Wayang Kulit: the Malay shadow play, literally meaning "leather play", on account of the materials used for making the shadow puppets. 


\section{Notes}

* Tengku Ahmad Hazri is a Research Fellow at IAIS Malaysia. He obtained his LLB (Hons) from the University of London, and was later attached to the International Movement for a Just World (JUST). Later he pursued his graduate studies at the International Institute of Islamic Thought and Civilization (ISTAC) in Kuala Lumpur. He may be reached at ahmhazri@iais.org.my

1. The exorcist role is not performed through the shadow play itself but is accomplished through the use of the puppets, rituals and some of the spells of the shadow play. Often this is done as part of the more explicitly exorcist art of main peteri. For a discussion on this, see Barbara S. Wright, "Dance Is the Cure: The Arts as Metaphor for Healing in Kelantanese Malay Spirit Exorcisms", Dance Research Journal, Vol. 12, No. 2 (Spring - Summer, 1980), pp. 3-10.

2. This classification is by no means exhaustive and different writers have assigned different names for the various wayang types.

3. Jeune Scott-Kemball, "The Kelantan Wayang Siam Shadow Puppets 'Rama' and 'Hanuman': A Comparative Study of their Structure”, Man, Vol. 59 (May, 1959), p. 73.

4. Ibid.

5. Ibid.

6. Hashim Yaacob, "Wayang Kulit Siam in the Malay Cosmology" in Faridah Noor Mohd Noor (ed.), Dimensions of Shadow Play in Malay Civilisation, Kuala Lumpur: Centre for Civilisational Dialogue, University of Malaya, 2006, p. 33.

7. Barbara Ann Stein Wright, Wayang Siam: An Ethnographic Study of the Malay Shadow Play of Kelantan, PhD Dissertation, Yale University, 1980, pp. 107-108.

8. Ibid., p. 3

9. Ibid.

10. Ziying, "Gifts of Life" in Star Two, The Star, 27 August, 2008, p. 23.

11. Ghulam-Sarwar Yousof, "The Malay Shadow Play as a Continuing, Changing Tradition," in Faridah Noor Mohd Noor (ed.), Dimensions of Shadow Play in Malay Civilisation, Kuala Lumpur: Centre for Civilisational Dialogue, University of Malaya, 2006, p. 28.

12. Haji Mubin Sheppard, "Pa' Dogol and Wa' Long: The evolution of the comedians in the Malay shadow play in Kelantan", Journal of the Malaysian Branch, Royal Asiatic Society, Vol. 38, Part 1 (1965), p. 2.

13. Barbara S. Wright, "Islam and the Malay Shadow Play: Aspects of the Historical Mythology of the Wayang Siam", Asian Folklore Studies, Vol. 40, No. 1 (1981), p. 54.

14. This makes sense if we recall that one of the purpose of the rituals was to make the play constantly attractive to the audience. Evidently for some dalangs, the 'audience' here has acquired a whole new meaning and it is not the play alone that can be made 'attractive'.

15. Barbara S. Wright, "Islam and the Malay Shadow Play," p. 59.

16. Ibid.

17. Mohd. Taib Osman, Bunga Rampai: Aspects of Malay Culture, Kuala Lumpur: Dewan Bahasa dan Pustaka, Kementerian Pendidikan Malaysia, 1988, pp. 182183. 
18. Barbara S. Wright, "Islam and the Malay Shadow Play," p. 54.

19. Ibid., pp. 56-58.

20. Amin Sweeney, Malay Shadow Puppets: The Wayang Siam of Kelantan, London: The Trustees of the British Museum, 1972, p. 60.

21. Haji Mubin Sheppard, "Pa' Dogol and Wa' Long," p. 1.

22. 'Ainu Sham Ramli \& Mohd. Azmi Ibrahim, Wayang Kulit: Warisan Teater Melayu, Kuala Lumpur: Perbadanan Kemajuan Kraftangan Malaysia, 1996.

23. Barbara S. Wright, "Islam and the Malay Shadow Play," p. 57.

24. Hashim Yaacob, "Wayang Kulit Siam in the Malay Cosmology" in Faridah Noor Mohd Noor (ed.), Dimensions of Shadow Play in Malay Civilisation, p. 28.

25. I Wayan Dibia, "Self Identity in Wayang Kulit Performance" in Faridah Noor Mohd Noor (ed.), Dimensions of Shadow Play in Malay Civilisation, p. 104.

26. Ibid., p. 107.

27. In one of the repertoire, Dollah Baju Merah said, "Pak Dogol tunggul bukan sebarang tunggul, / di luarnya tunggul di dalamnya ramai. / Buruk bukan sebarang buruk, di luarnya buruk / di dalamnya bertuah. I Pak Dogol jangan dicaci kelak majal ketulah / diri membawa mati", which roughly translates into "There is more to Pak Dogol's simplicity than meets the eye, / simple on the outside, yet rich on the inside. / More to his ugliness than meets the eye, ugly on the outside / fortune and beauty on the inside. / Curse not Pak Dogol / for that shall bring curse unto the one who cursed." See Hashim Yaacob, "Wayang Kulit in the Malay Cosmology", Faridah Noor Mohd Noor (ed.), Dimensions of Shadow Play in Malay Civilisation, p. 28.

28. This is a famous hadith of Prophet Muhammad (pbuh).

29. "The three grand revelations of the Real, or theophanies, namely, the cosmos or macrocosm, man or the microcosm, and religion, all comprise forms which lead to the formless, but only the third enables man to penetrate the world beyond forms, to gain a vision of forms of both the outer world and his own soul, not as veil but as theophany." See Seyyed Hossein Nasr, Knowledge and the Sacred, Lahore: Suhail Academy, 1988, p. 261.

30. Amin Sweeney, The Ramayana and the Malay Shadow Play, Kuala Lumpur: National University of Malaysia Press, 1972, p. 13.

31. Amin Sweeney, The Ramayana and the Malay Shadow Play, p. 42.

32. Ibid, p. 44.

\section{References}

'Ainu Sham Ramli \& Mohd. Azmi Ibrahim, Wayang Kulit: Warisan Teater Melayu, Kuala Lumpur: Perbadanan Kemajuan Kraftangan Malaysia, 1996.

Burckhardt, Titus, Sacred Art in East and West: Principles and Methods, Middlesex: Perennial Books, 1967.

Faridah Noor Mohd Noor (ed.) Dimensions of Shadow Play in Malay Civilisation, Kuala Lumpur: Centre for Civilisational Dialogue, University of Malaya, 2006.

Farish A. Noor, From Majapahit to Putrajaya: Searching for Another Malaysia, Kuala Lumpur: Silverfishbooks, 2005. 
Farish A. Noor, The Other Malaysia: Writings on Malaysia's Subaltern History, Kuala Lumpur: Silverfishbooks, 2002.

Ghulam-Sarwar Yousof, The Malay Shadow Play: An Introduction, Penang: The Asian Centre, 1997.

Hassan Othman, Wayang Gedek: Warisan Kesenian Melayu, Kuala Lumpur: Kementerian Kebudayaan, Kesenian dan Pelancongan, 2003.

Kertas Kerja Festival Wayang Nusantara “Wayang Dalam Bayang”, Kuala Lumpur: Akademi Seni Kebangsaan, 2001.

Mohd. Taib Osman, Bunga Rampai: Aspects of Malay Culture, Kuala Lumpur: Dewan Bahasa dan Pustaka, Kementerian Pendidikan Malaysia, 1988.

Nasr, Seyyed Hossein, Islamic Art and Spirituality, Ipswich: Golgonooza Press, 1989.

Nasr, Seyyed Hossein, Knowledge and the Sacred, Lahore: Suhail Academy, 1988.

Osnes, Mary Beth, "Malaysia's Evolving Shadow Puppet Theatre", Asian Theatre Journal, Vol. 9, No. 1 (Spring, 1992), pp. 112-116.

Scott-Kemball, Jeune, “The Kelantan Wayang Siam Shadow Puppets 'Rama' and 'Hanuman': A Comparative Study of their Structure”, Man, Vol. 59 (May, 1959), pp. 73-78.

Sheppard, Haji Mubin, “Pa' Dogol and Wa' Long: The evolution of the comedians in the Malay shadow play in Kelantan", Journal of the Malaysian Branch, Royal Asiatic Society, Vol. 38, Part 1 (1965), pp. 1-5.

Sweeney, Amin, Malay Shadow Puppets: The Wayang Siam of Kelantan, London: The Trustees of the British Museum, 1972.

Sweeney, Amin, The Ramayana and the Malay Shadow Play, Kuala Lumpur: National University of Malaysia Press, 1972.

Wright, Barbara S., "Dance Is the Cure: The Arts as Metaphor for Healing in Kelantanese Malay Spirit Exorcisms", Dance Research Journal, Vol. 12, No. 2 (Spring - Summer, 1980), pp. 3-10.

Wright, Barbara S., "Islam and the Malay Shadow Play: Aspects of the Historical Mythology of the Wayang Siam”, Asian Folklore Studies, Vol. 40, No. 1 (1981), pp. 51-63.

Wright, Barbara Ann Stein, Wayang Siam: An Ethnographic Study of the Malay Shadow Play of Kelantan, PhD Dissertation, Yale University, 1980. 